Bond University

Research Repository

\title{
An investigation of hindsight bias in nascent venture activity
}

Cassar, Gavin; Craig, Justin

Published in:

Journal of Business Venturing

DOI:

10.1016/j.jbusvent.2008.02.003

Licence:

CC BY-NC-ND

Link to output in Bond University research repository.

Recommended citation(APA):

Cassar, G., \& Craig, J. (2009). An investigation of hindsight bias in nascent venture activity. Journal of Business Venturing, 24(2), 149-164. https://doi.org/10.1016/j.jbusvent.2008.02.003

\section{General rights}

Copyright and moral rights for the publications made accessible in the public portal are retained by the authors and/or other copyright owners and it is a condition of accessing publications that users recognise and abide by the legal requirements associated with these rights.

For more information, or if you believe that this document breaches copyright, please contact the Bond University research repository coordinator. 


\title{
Bond University
}

\section{ePublications@bond}

3-1-2009

\section{An investigation of hindsight bias in nascent venture activity}

\author{
Gavin Cassar \\ Justin B. Craig \\ Bond University, justin_craig@bond.edu.au
}

Follow this and additional works at: http://epublications.bond.edu.au/acfb_pubs

Part of the Business Administration, Management, and Operations Commons

\section{Recommended Citation}

Gavin Cassar and Justin B. Craig. (2009) "An investigation of hindsight bias in nascent venture activity" Journal of business venturing, 24 (2), 99-196.

http://epublications.bond.edu.au/acfb_pubs/2 


\title{
AN INVESTIGATION OF HINDSIGHT BIAS IN NASCENT VENTURE ACTIVITY
}

\author{
Gavin Cassar \\ The Wharton School \\ University of Pennsylvania \\ Office: 1309 Steinberg Hall-Dietrich Hall \\ Phone: +1 2158982023 \\ Email: cassar@wharton.upenn.edu \\ Web: http:/www.wharton.upenn.edu/faculty/cassar.html \\ SCHOOL OF BUSINESS, TECHNOLOGY AND SUSTAINABLE DEVELOPMENT \\ BOND UNIVERSITY \\ AUSTRALIA \\ TEL: 55951161 \\ FAX: 55951160 \\ jcraig@bond.edu.au
}

\begin{abstract}
We posit that individuals who are actively engaged in activities to develop their own venture will exhibit hindsight bias when recalling their startup experiences. We observe that those who fail to develop their startup activity into an operating business demonstrate substantial hindsight bias concerning the probability of venture formation. In particular, the recalled probability of success, reported after their decision to quit, is lower than the probability of success solicited during the nascent process. We argue that the systematic distortion of the past has important implications for individuals involved in the venturing process. Specifically, we suggest that these individuals are at risk of overestimating their chances of success when starting future nascent activity if they do not correct for their optimistic tendencies. The evidence from this study suggests it is important to recognize that what nascent entrepreneurs believe they experienced, and what they actually experienced, may not be equivalent.
\end{abstract}




\section{Executive summary}

The majority of actions performed and investments made by individuals in attempting to start a new business are in vain. While unsuccessful nascent activity may result in considerable emotional costs and lost time and financial capital, several academics argue that individuals benefit from learning by undertaking the startup process. Through the experience of venturing, individuals can learn from mistakes made during the process. Individuals can also learn about themselves, such as their strengths and weaknesses in regard to different venturing tasks. For example, through observation of their initial beliefs and comparison with the eventual outcome, individuals can evaluate their ability to accurately make predictions about future venture opportunities and endeavors. Further, individuals may be able to improve their abilities to make accurate predictions. However, such improvement may only be achieved if individuals can accurately recall their beliefs and outcomes from previous nascent activity. If individuals can not accurately recall their experiences or environment, this diminishes the ability to improve their prediction of future opportunities.

Individuals’ inability to accurately recall is influenced by hindsight bias. Hindsight bias describes the tendency for individuals to see past events as being more predictable, or to believe after an event, that their prediction of the outcome was more accurate than it actually was. We predict that hindsight bias will result in a biased, or systematically distorted, recreation of the past. In other words, nascent entrepreneurs will not only incorrectly recall their previous beliefs, but they will recall their beliefs incorrectly in a predictable direction. In this paper, we investigate the extent to which nascent entrepreneurs exhibit hindsight bias from failed nascent activity and what factors may be associated with this bias. 
Specifically, using the Panel Study of Entrepreneurial Dynamics, we examine differences in 198 nascent entrepreneurs' perceptions using a simple longitudinal design, before and after nascent activity. First, during the early stages of venturing, we asked the likelihood their startup will become an operating business. Second, we longitudinally identified those individuals that failed to create an operating business. Third, we asked these individuals what was the likelihood that their startup would become an operating business when they initially became involved in the startup. The difference between the reported likelihood during the nascent process and the recalled likelihood after the decision to quit is the observed bias.

This research makes two important contributions. First, we demonstrate strong hindsight bias in those individuals who quit their nascent activity, with the mean (median) bias observed being 18.5 percent (20.0 percent). Therefore, consistent with our conjectures, we find a biased component to nascent entrepreneurs' recall about past nascent activities, namely the potential for success. Further, we examine cross-sectional differences in hindsight bias based on demographic characteristics and duration of recall. Aside from the most formally educated, we observe the presence of hindsight bias in the retrospective recall ability to be widespread across nascent entrepreneurs.

Second, we argue that hindsight bias can directly affect what individuals actually experience from engaging in the business start-up process. We argue that hindsight bias will affect the individual's nascent experience in predictable ways through the distortion of recalled information. Subsequently, individuals who consistently overestimate the success of venture opportunities may not become aware of their optimistic tendencies when evaluating future venture opportunities. Optimistic overentry by entrepreneurs will continue where the performance feedback necessary to correct it is relatively noisy, infrequent, or slow. We argue 
that, when recalled by nascent entrepreneurs, performance feedback is not just noisy but also biased.

We further contend that a lower recalled likelihood of success allows individuals to ignore other explanations for failure. Inaccurate explanations for failure due to distorted recollection will lead to individuals not addressing ways to overcome these concerns and believing they still possess the necessary abilities to undertake successful venturing. Hence, by establishing the presence of hindsight bias in failed nascent entrepreneurs we explain why individuals have a propensity to engage in serial nascent entrepreneurship, even after failed startup attempts. Consequently, we move the discussion beyond concerns associated with the use of retrospective accounts in empirical research, and propose that hindsight bias matters for future nascent activity. 


\section{Introduction}

How does what individuals experience from immersion in nascent activity affect future nascent activity? Most activity undertaken by those who are actively engaged to develop their own venture (nascent entrepreneurs) does not result in a successful or even an operating business (Gartner, Shaver, Carter, \& Reynolds 2004; Reynolds, 1997). Thus, considerable costs can be incurred during this nascent stage, such as lost time and financial capital. Several researchers, however, argue that there are benefits from failed nascent activity due to learning that is achieved by being involved in the startup process (e.g., Bird, 1992; Carter, Gartner, \& Reynolds, 1996). In this paper, we focus on hindsight bias in nascent activity and what affects this bias. We argue that examining hindsight bias is important because hindsight bias has the potential to affect future nascent activity.

Ex-ante expectations, based on prior knowledge and experience applied to a particular setting, underlie the choice to undertake nascent activity (Shane \& Venkataraman, 2000). Individuals pursuing business start-up continually evaluate expected opportunity costs of venturing against expected returns from undertaking nascent activity and operating a venture (Cassar, 2006a; Gimeno, Folta, Cooper, \& Woo, 1997). During this period, expectations that effect the decision to start (success), or abandon (failure), the venture (Honig, Davidsson, \& Karlsson, 2005; Sarasvathy, 2001) are adjusted. Further, these new experiences and knowledge influence, and arguably, improve the accuracy of expectations related to future nascent activity (Carter, et al., 1996; Parker, 2006; Starr \& Bygrave, 1992).

If individuals can not accurately recall their experiences, environment, or circumstances from previous nascent activity, the ability to refine or improve their evaluation of future opportunities is diminished. Individuals’ inability to accurately recall is influenced by hindsight 
bias, which leads to a systematically distorted recreation of the past (Bukszar \& Connolly, 1988). Hindsight bias describes the tendency for individuals to see past events as being more predictable, or to believe after an event, that their prediction of the outcome was more accurate than it actually was. We argue that hindsight bias will lead to individuals superimposing their recollections of previous experiences so that it makes sense when evaluating future startup prospects (Roese \& Olson, 1996).

In this research, we examine the accuracy and bias in nascent entrepreneurs' perception of achieving a successful outcome, specifically, the launching of the business, pre and post the nascent activity. We operationalize this by asking, during the nascent process, their likelihood of actually starting a business. Then, after the individuals reported that they had not started a business, they were asked to recall what the likelihood was that their start-up would become an operating business when they initially became involved in the nascent activity. We argue that, due to hindsight bias, there is a biased systematic component to retrospective recall that results in predictable errors in recalled information about past nascent activities, and that this will influence how individuals benefit from their immersion in nascent activity. Further, we examine potential cross-sectional moderators of hindsight bias based on the demographics of the nascent entrepreneur and temporal period of recall.

Nascent activities are crucial for developing entrepreneurial knowledge (Corbett, 2005). However, our argument is that knowledge accrual as a consequence of nascent activity is a function of the accuracy of recall. The greater the error between what the individual believed they thought was going to occur, in this case, the probability of achieving the operating venture, and the recalled probability of achieving the operating venture, the less likelihood the nascent entrepreneur develops knowledge about the venture evaluation process. Some researchers 
suggest that there are impediments to learning that make it harder (noisier) for the entrepreneur to recall and learn from failed venturing activity (Shepherd, 2003). We propose that hindsight bias will affect future entrepreneurial behavior. For example, if the nascent entrepreneur consistently overestimates the ex-ante viability of venture opportunities, and, due to hindsight bias, consistently recalls a lower evaluated ex-ante venture viability, they may not be cognizant of the role of biased retrospective recall when evaluating future venture opportunities. Camerer and Lovallo (1999) state that optimistic overentry will persist if the performance feedback necessary to correct it is relatively noisy, infrequent, or slow. In this context, noisy performance feedback occurs when there are large differences, or errors, between what actually happened and what the individual believed or recalled happened. Our argument is that performance feedback, when recalled by nascent entrepreneurs, is not just noisy, but systemically biased. We further suggest that the presence of hindsight bias in failed nascent entrepreneurs contributes to the presence of optimism in entrepreneurial endeavors, even after negative outcomes. Consequently, by linking hindsight bias to this issue, we focus beyond concerns associated with the use of retrospective accounts in empirical research and argue that bias matters for future nascent activity.

The following section provides the theory development. Section three presents the hypotheses. Section four discusses the sample and variables. The findings are presented in section five. A discussion of the implications is presented in section six. Section seven concludes the paper. 


\section{Theory development}

\subsection{Hindsight Bias}

Hindsight bias is the cognitive process by which individuals superimpose structure and simplicity on their recollections of the past (Roese \& Olson, 1996). Hindsight bias describes the tendency for individuals to see past events as being more predictable, or to believe after an event, that their prediction of the outcome was more accurate than it actually was. Unbeknown to them, this revised schematic representation has a powerful effect on the causal structure of past outcomes (Fischhoff, 1975). Outcomes (consequences) are associated with the selective recall of antecedent information. The antecedents that are more likely to be recalled are those that are promoted as having causal links to the outcome (Hawkins \& Hastie, 1990). This results in individuals being convinced after-the-fact that the outcome was predictable before the act (Roese \& Olson, 1996).

Making sense of the past is the focal point of hindsight bias. As such, researchers have explored, for example, contributions of outcome valence and expectancy as triggering factors (Olson, Roese, \& Zanna, 1996; Fischhoff, 1975); using hindsight bias to explain the way we evaluate the actions of others (Hertwig, Fanselow, \& Hoffrage, 2003); and how hindsight bias damages formal decision-making processing (Christensen-Szalanski \& Willham, 1991).

Previous experimental evidence of hindsight bias generally alludes to failure evoking a larger hindsight bias than success and that unexpected failure produces a particularly strong bias (Schkade \& Kilburne, 1991; Wasserman, Lempert, \& Hastie, 1991). There is some consensus in this experiment-based literature that hindsight bias is shaped by processes of recollection and reconstruction (Erdfelder \& Buchner, 1998). This body of work, based on laboratory experiments, usually simulations, indicates that hindsight bias is the sum of multiple 
determinants. All else being equal, hindsight bias is a combination of the amount of foresight knowledge individuals possess, the proportion of false knowledge that interferes with this knowledge, and the degree to which feedback updates their missing knowledge (Hertwig et al., 2003).

Hindsight effect research in business settings has put forward a variety of constructs that may act as moderators (Huber \& Power, 1985). Huber and Power (1985) highlight that individual perceptual biases are linked to their particular organizational roles i.e., first hand situational exposure (Dearborn \& Simon, 1958). The influence of previous general or work experience has also been shown to influence cognitive biases (Honig et al., 2005; Lamont, 1972; Ronstadt, 1988). Though laboratory research suggests that the more experience/expertise individuals have with the task under consideration, the smaller the resulting hindsight bias (Christensen-Szalanski \& Willham, 1991; Hertwig et al., 2003), Golden’s (1992) field research found that formal business education and years spent with the organization (experience) did not influence recall. Age of the individual has also been shown to influence information processing and decision making performance. For example, Taylor (1975) found that older decision makers tended to take longer to reach decisions, were able to diagnose the value of information more accurately, were less confident with their decisions and were more flexible to change a decision, than were younger decision makers.

Another potential moderating influence in accurate recall, intuitively, relates to the duration of time between data collection points, with the longer the temporal period of recall, the greater the potential for hindsight bias to be exhibited. Generally, temporal affects in the extant literature reports results from laboratory experiments using limited time intervals, such as only a few hours (Guilbault et al., 2004). 
Regardless, because, in retrospect, it is widely accepted that people see the world as unfolding toward the present (Bukszar \& Connolly, 1988), in our nascent entrepreneurial context, we contend that hindsight bias occurs when recall of actual details or events during the start-up-stage are influenced by the individual's inability to accurately retrieve their original perspective. Accompanying this is a denial that the outcome information influences their judgment (Wasserman et al., 1991). Fischhoff (1982) suggests that outcome knowledge, which contributes to a feeling of understanding the past, prevents individual learning. Hence, we posit that important lessons go unlearned due to the affect of hindsight bias.

\subsection{The Nascent Process}

Given the dynamic nature of the entrepreneurial environment, any act of entrepreneurship, including nascent activity, can change the content of an individual's knowledge. Nascent activity provides individuals with considerable opportunities for distilling and interpreting direct and indirect feedback, which enables the making sense of the dynamic entrepreneurship environment (Harrison \& Leitch, 2005; Minniti \& Bygrave, 2001; Parker, 2006). However, this making sense reflectively is influenced by an inclination to build in personal biases i.e., in evaluating a situation after the fact, the individual is prone to distort the circumstances.

Even so, nascent activity allows those immersed in it access to new knowledge about, for example, market forces, which equips the nascent entrepreneur to be better able to make strategy-related decisions (Gartner, 1985). Likewise, individuals can better understand the fit between themselves and the potential opportunity and what it takes to pursue an entrepreneurial career (Hoang \& Gimeno, 2005). As well, they gain valuable first-hand insight about the process 
involved in evaluating a potential opportunity, regardless of their decision to proceed or quit (Carter et al., 1996; Corbett, 2005, 2007; Dutta \& Crossan, 2005; Westhead, Ucbasaran, \& Wright, 2005).

Failure to proceed with a nascent venture enables the understanding of previous uncertainties, and provides an opportunity to pinpoint why problems occur (e.g., Maidique \& Zirger, 1984; McGrath, 1999; Nonaka \& Takeuchi, 1995; Sitkin, 1992; Weiner \& Kulka, 1970). Further, abandoning a nascent venture is often an "intelligent” failure as this decision provides a basis for altering future behavior through new information (Sitkin, 1992). Failure at the nascent stage facilitates the pursuit of new approaches and stimulates learning through experimentation (Politis, 2005; Sarasvathy, 2001).

Through the observation of past events, individuals can update their prior beliefs regarding their entrepreneurial ability, the venture opportunity, and their accuracy in evaluating opportunities (Lumpkin \& Lichtenstein, 2005; Shane 2000). However, learning is not automatic in entrepreneurship (McGrath, 1999; Sexton, Upton, Wacholtz, \& McDougall, 1997). These learning models, though, make an important assumption, specifically, that the individual will have accurate and unbiased recall and interpretation of past events. For example, individuals are prone to interpret feedback in self-affirming ways (Kahneman, Slovic, \& Tversky, 1982). This phenomenon leads the nascent entrepreneur to make wrong decisions as information that may render their assumptions incorrect is rejected (Swann, 1997; Swann \& Hill, 1982). Further, if individuals can not recall without bias their experiences, environment, and circumstances from previous entrepreneurial activity, the ability to refine or improve their venture opportunity evaluation for future opportunities, is diminished (Westhead et al., 2005). 
As an illustrative example, consider an individual who evaluates the viability of a venture as a function of an observed signal that is interpreted with some error. This ex-ante viability determines whether the individual will undertake nascent activities to pursue the opportunity. Through the partial or full observation of the actual venture viability, the individual can update their priors about both the viability of the venture opportunity and the errors made in the evaluation process. If the individual evaluates the ex-ante viability of venture opportunities with optimistic errors, through observation and reflection of past outcomes, optimistic evaluation errors may be reduced. In particular, the feedback from observing optimistic errors when evaluating the viability of venture opportunities should result in correction of individuals' optimistic tendencies. However, revising the above example, if the individual overestimates the ex-ante viability of venture opportunities, and, as a consequence of hindsight bias, consistently recalls a lower ex-ante venture viability, they may not be aware of optimistic beliefs and hold them when evaluating future venture opportunities. Therefore, the nascent entrepreneur's appreciation of errors in their own venture evaluation process is a function of the ability to observe and recall previous evaluation processes both accurately and without bias.

The inability to refine their recall capabilities from nascent activities has implications for what individuals know about themselves. A lower recalled likelihood of success will allow the individual to ignore other explanations for failure, such as their insufficient talent for evaluating potential venture opportunities or lack of ability to execute the required activities to start the venture (Shaver et al., 2001). Distorted recall affects how individuals evaluate their own skills. By not being aware of other explanations for failure from nascent activity, individuals will not address ways to overcome these concerns. Hence, the presence of hindsight bias in failed nascent 
entrepreneurs may help explain the presence of optimism in entrepreneurial endeavors, even after previous negative outcomes (McMullen \& Shepherd, 2006).

This study complements research on entrepreneurial attribution. Attribution theory offers an account of the way in which individuals explain their and others' actions (Kelley, 1972; Shaver, 1985). When explaining the successful or unsuccessful performance of a task, individuals primarily concentrate on four explanatory factors: the individual's innate ability, the level of effort exerted, the difficulty of the task, and the presence of luck (Heider 1958). Researchers have traditionally distinguished between attributed causes of events by locus of causality, whereby individuals attribute the outcome to those factors internal to the individual and those factors located in the external environment (Weiner, 1985). The greater the importance of attributed internal causes, the more the individual is perceived to be responsible for the event.

How one attributes behavior and outcomes has been argued to have implications for individuals' emotional reactions and future expectations (Weiner, 1985). In this study's context, an individual who attributes failure to external factors, such as bad luck, will not revise their beliefs regarding their ability or task difficulty of venture initiation. In contrast, an individual who attributes failure to internal factors will have lower expectations about future venturing activity and may feel shame. However, acknowledging a deficiency, such as insufficient ability, allows the individual to take corrective actions to address the identified concerns, such as investing in their human capital. Therefore, the individual's interpretation of the success or failure may be more important than the fact of success or failure in regard to the individual's future behavior and performance (Shaver et al., 2001). Consequently, both hindsight and attribution biases, are argued to influence future entrepreneurial endeavors, as both affect what is learnt by the individual in the venturing process. In the current research, rather than focus on 
how entrepreneurs' attribute causes of their failure in a biased manner, we focus on how entrepreneurs can distort what they observed or expected during venturing when recalling their observations and beliefs.

\section{Hypotheses}

We posit that hindsight bias occurs when entrepreneurs who abandon a nascent venture are called upon to recall their initial perceived chances and subsequent chances of success. Specifically, nascent entrepreneurs who abandoned nascent activity will perceive, after the fact, that the outcome was more predictable than perceived before the fact. Further, nascent entrepreneurs will recall their prior prediction of the event, in this case that the nascent activity would not result in an operating venture, was more accurate than was actually predicted. Hence, consistent with our discussion of the existence of hindsight bias, we hypothesize that nascent entrepreneurs who decide not to proceed with their venture will recall a lower initial probability of success than they espoused during the nascent process.

\section{Hypothesis 1: The probability of successful launch that nascent entrepreneurs} initially report will be higher than the recalled probability of success that they report after their decision to quit the nascent activity.

Previous researchers have suggested that demographic characteristics could moderate the affect of cognitive biases. Though some suggest that experience may fortify cognitive biases (Weinstien, 1982), there is limited experimental evidence in the literature that hindsight bias is reduced by intense involvement with a topic that comes with a professional education (Fischhoff, 
1982). In one study that tested for the existence of hindsight bias in 160 experienced and trainee physicians, Dawson et al. (1998) established that hindsight bias was significantly more evident in physicians with less experience. In other professional contexts that have investigated the way in which base rate information is learned and used by decision-makers, Christensen-Szalanski and Bushyhead (1981) showed that physicians who learned the low base rates from their clinical experience relied heavily on this base rate when making diagnoses. Christensen-Szalanski and Beach (1982) further showed that personally experienced base rates were used only by those who also experienced the relationship between the base rate and the diagnostic information. Hence, it would seem that first hand situational exposure influences cognitive bias, in particular, the ability to recall. That extant findings of the role of moderators are inconclusive impelled us to empirically examine how experience and knowledge affect the recall of nascent entrepreneurs. In particular, whether the difference between the probability of successful launch initially reported and the recalled probability of success reported after the decision is made to quit the nascent activity is lower for nascent entrepreneurs with more formal education, with more startup experience, or who are older.

Hypothesis 2a: Hindsight bias is lower for nascent entrepreneurs with more formal education.

Hypothesis 2b: Hindsight bias is lower for nascent entrepreneurs with more start-up experience.

Hypothesis 2c: Hindsight bias is lower for older nascent entrepreneurs. 
We are further interested to examine how temporal artifacts affect hindsight bias in nascent entrepreneurs. Specifically, whether the difference between the probability of successful launch initially reported and the recalled probability of success reported after the decision is made to quit the nascent activity is positively associated with the number of months between responses.

Hypothesis 3: Hindsight bias in nascent entrepreneurs increases with time.

Evidence from psychology also suggests that individuals perceive their abilities are superior to their peers (Larwood \& Whittaker, 1977) and also they perceive that favorable events are more likely to happen to them than their peers (Taylor \& Brown, 1988). For example, Cooper, Woo, and Dunkelberg (1988) observed that entrepreneurs perceived their chances of success to be significantly higher than their self-reported odds of success for similar businesses. After failure to launch the venture, how an individual perceives their chances of launching their ventures in comparison to other individuals trying to launch similar ventures is an empirical question. With the experience of failure to launch, individuals may no longer exhibit beliefs that their chances of success were greater than that of others. Further, if individuals recall their chances of success were better than others, and yet failed, it may be difficult for the individual to reconcile why they failed. Therefore, through negative feedback, individuals may perceive themselves to be the same as or worse than their peer group. Alternatively, given the pervasive inclination for individuals undertaking venturing to consider themselves more likely to succeed than their peers, they may maintain these beliefs even after failure. Given the extant empirical evidence, we hypothesize the latter argument. 
Hypothesis 4: The nascent entrepreneur's recalled expectation of launching their venture will be greater than their expectation of others launching similar ventures.

\section{Method}

\subsection{Sample}

The Panel Study of Entrepreneurial Dynamics (PSED) was utilized to investigate hindsight bias in nascent entrepreneurs. The distinctive feature of the PSED is that it identifies and surveys nascent entrepreneurs in the process of starting new ventures (Gartner et al., 2004). ${ }^{1}$ Further, the longitudinal nature of the survey allows the tracking of individuals through the startup process into eventual operation or inactivity. The use of longitudinal field data lends itself to an investigation of hindsight bias, due to the ordering of events, namely: (1) ex-ante beliefs; (2) outcome; and (3) recalled beliefs. The lack of field data with this temporal ordering, may explain the absence of hindsight bias research in the extant entrepreneurship literature and the dearth of non-experimental (i.e., field) studies in the broader hindsight bias literature. Therefore, the PSED provides a novel dataset to examine hindsight bias.

The screening process involved approximately 60,000 individuals from the mainland United States. These individuals, who undertook telephone interviews, were selected using random digit dial procedures. To be classified as a nascent entrepreneur the respondent had to exhibit the following two characteristics: (1) they expect to have at least some ownership in the new firm; (2) they had to be actively trying to start the new firm in the past 12 months. Of the

${ }^{1}$ Research using data, questions, or research designs developed from the PSED has been published in numerous mainstream management and entrepreneurship based journals including: Entrepreneurship Theory and Practice, Journal of Business Venturing, Journal of Management, Journal of Small Business Management, Small Business Economics, Strategic Management Journal, and Management Science. 
respondents satisfying the screening criteria, further selection and volunteering criteria resulted in 830 nascent entrepreneurs being subsequently phone interviewed. Nascent entrepreneurs for this study were determined as those attempting to start a new business, but not on behalf of an employer. These two criteria ensure that the expectations observed relate specifically to the respondent's venturing activity rather than as a consequence of undertaking entrepreneurial activities on another person's behalf. Further, all venturing activity which reported positive cash flows for greater than three months at the time of phone survey were removed, to ensure the venture was still in the start-up phase. This resulted in a sub-sample of 705 nascent entrepreneurs.

The status of the startup activity was asked in up to three subsequent phone interviews. We limit the sample to those who identified that the startup activity was: (1) no longer pursued by the respondent; and, if applicable (2) not pursued by others (of the team) to the point that the startup was an operating business. These criteria ensure that the startup on which the respondent based their perceptions of success (operation) was not successful (not operating). The examination of unsuccessful individuals is ideally suited to investigate hindsight bias, given experimental evidence that suggests unexpected failure generally evokes larger hindsight bias than unexpected success (Schkade \& Kilburne, 1991; Wasserman et al., 1991; Guilbault et al., 2004). Therefore, investigating individuals who fail increases the power to identify potential cross-sectional variation in hindsight bias. Of the 542 respondents who had reported in future phone interviews the status of their startups, we identified 208 (38.4 percent) who quit the startup process. The final sample of 198 nascent entrepreneurs provided ex-ante and recalled expectations of the likelihood of their startup becoming an operating business. 
As the greater the actual venture activities undertaken, the more the decision to quit could be categorized as failure, we examined the extent to which respondents had undertaken venture organizing activities. Of the sample of 198 nascent entrepreneurs who quit, 182 (91.9\%) had invested their own money in the business, 145 (73.2\%) had purchased raw materials, inventory or supplies, and 82 (41.4\%) were devoted full-time (35 or more hours per week) to the business at some point ${ }^{2}$. This suggests that many of the sample nascent entrepreneurs who quit had progressed beyond the idea stage and invested resources.

\subsection{Variables}

\subsubsection{Expectations}

The solicited expectations capture the entrepreneurs’ beliefs during and after the failed nascent activity. The expectation of the likelihood of the startup becoming an operating business was obtained from the first phone interview. Specifically, the respondent was asked "on a scale of zero to one hundred, what is the likelihood that this business will be operating five years from now, regardless of who owns and operates the firm?” This response is defined as the ex-ante expectation.

Those who responded in a subsequent phone interview that their nascent venture was no longer pursued, were asked to recall their likelihood of achieving an operating business when they became involved in the nascent activity. Specifically, the recalled expectation was defined as the response to "when you got involved in this start-up, what was the probability that it would become an operating business?” A positive difference between the ex-ante expectation and the

\footnotetext{
${ }^{2}$ For a limited sample $(n=97)$, there was also information concerning the number of hours invested by the respondent. The mean (median) number of hours devoted in the start-up was 1,005 (300). Given the most recent response for the time invested was generally obtained from the initial survey $(n=79,81.4 \%)$, this response likely understates the total hours invested before the decision to quit for the sample.
} 
recalled expectation would be consistent with predicted direction associated with hindsight bias related to an unfavorable outcome ${ }^{3}{ }^{4}$. The use of objective probability estimates rather than subjective estimates, such as scales anchored by very unlikely and very likely, increases the likelihood of detecting hindsight bias (Guilbault et al., 2004).

To determine how ex-ante expectations and recalled expectations of the startup activity of nascent entrepreneurs compare with how they perceive the chances of success of other similar startups after failure, the response to a further question from the phone interview was analyzed. Specifically, "given your recent experience, what probability would you now give to a similar start-up to become an operating business?” This question allows investigation, directly, of the presence of bias, and indirectly the role of learning, in nascent entrepreneurs after a negative outcome, namely the failure to start a business from their startup activity.

\subsubsection{Independent variables}

The experience/expertise of the respondent was determined by two variables. First, whether they were a small business owner or self-employed during the nascent activity. Second, the age of the respondent, which is represented as a continuous variable denoted in years. Education of the respondent was represented as a series of dummy variables indicating the highest level of formal education achieved, being: (1) up to college; (2) college; and (3) post

\footnotetext{
${ }^{3}$ The correlation between the ex-ante expectation and the recalled expectation is 0.15 , suggesting that a hindsight bias measure based on the difference between these two expectations should be reliable (Bergh and Fairbank, 2002).

${ }^{4}$ The extent to which the probability of achieving venture operation on the day the individual started the nascent activity differs from the probability of achieving venture operation solicited at the first survey during the nascent process is a limitation of the study. Obtaining a real-time solicitation of beliefs from individuals at the start of nascent activity is problematic, given initial involvement may occur at any point in time and the response must be solicited at that moment in time. Importantly, failure to capture any potential differences in beliefs between these two points in time will effectively bias against the study design detecting hindsight bias.
} 
college. The use of dummy variables instead of a single continuous variable does not constrain variations in hindsight bias to be linearly associated with higher educational attainment. The time between the initial survey and the survey when they reported they had quit their nascent activity is a continuous variable denoted in months.

\subsection{Sample beliefs concerning learning and future nascent activity}

To underscore the importance of investigating hindsight bias in failed nascent entrepreneurs and its linkages to learning and future nascent activity, it is instructive to present the sample nascent entrepreneurs' responses from two questions. The first question was related to perceived learning from the failed startup activity. Specifically, respondents were asked "if you got involved in another start-up, do you think the chances it would become an operating business will be: (1) better; (2) about the same; or (3) worse; than for this last startup effort?” Examining the frequencies, the majority of respondents perceive that the future chances of creating an operating business will be improved after undertaking a failed startup, with 86.4 percent $(n=171)$ selecting 'better' and 1.5 percent $(n=3)$ selecting 'worse'. This suggests that nascent entrepreneurs perceive that they learn from the failed nascent experience.

The second question examines the enthusiasm towards undertaking future nascent activity. Specifically, respondents were asked "would you say that you expect to be involved in another start-up: (1) never again; (2) under the right conditions; or (3) most certainly?” If nascent entrepreneurs are discouraged from undertaking venturing activity after failure, there would be limited benefit in understanding learning after failure. Examining the responses, more failed nascent entrepreneurs expect to be involved in another start-up than not, with 38.6 percent responding 'most certainly’ and 1.7 percent responding 'never again'. This highlights the desire 
of individuals, even after negative outcomes, to continue entrepreneurial activity and underscores the importance of examining learning issues related to startup failure.

\section{Results}

\subsection{Test of hindsight bias}

Table 1 presents the ex-ante expectation, recalled expectation, and hindsight bias. Nascent entrepreneurs who eventually quit their startup activity have a mean (median) ex-ante expectation of 77.3 percent (80 percent) that their startup will become an operating business. The recalled mean (median) expectation that the startup would become an operating business, asked after the startup activities have been abandoned by the respondent and any other team member, is 58.8 percent (50 percent). The mean (median) hindsight bias is 18.5 percent (20.0 percent). This difference between expectations is statistically significant at $p<0.001$ for both parametric and non-parametric tests. This result is consistent with hypothesis one which suggests that failed nascent entrepreneurs will recall a lower probability of the likelihood of the venture becoming operational.

The mean (median) absolute hindsight bias is 30.4 (25 percent), which demonstrates that the retrospective recall of failed nascent entrepreneurs’ exhibits considerable noise. However, the significant difference in the signed recall error, suggests that the recalled accounts of these individuals are not just noisy, but biased.

Insert Table 1 about here 


\subsection{Cross-sectional differences in hindsight bias}

The correlations between hindsight bias and the independent variables in presented in Table 2. Table 3 reports the tests for cross-sectional differences in retrospective recall. The sample size is reduced to 194 due to four participants not providing responses for all the independent variables. Generally, the independent variables provided limited explanatory power in predicting cross-sectional differences in hindsight bias. The one variable that did provide explanatory power, consistent with Hypothesis 2a, was education, with those nascent entrepreneurs with post-college educational attainment having significantly lower hindsight bias $(p<0.05)$. However, examining cross-sectional differences in nascent entrepreneur startup experience $(\mathrm{H} 2 \mathrm{~b})$ or age $(\mathrm{H} 2 \mathrm{c})$ suggests that these characteristics are not significantly associated with hindsight bias. Therefore, the only support for hypothesis two is the finding that those nascent entrepreneurs with higher educational attainment appear to have lower hindsight bias.

\section{Insert Table 2 about here}

Interestingly, the number of months between surveys did not exacerbate respondents hindsight bias (H3). Given the minimum time between the initial survey and the quitting survey was 11 months, this temporal period may have allowed hindsight bias to fully manifest in failed nascent entrepreneurs. Consequently, adding additional months between the ex-ante and recalled expectations will not contribute to further increases in directional hindsight bias. ${ }^{5}$

\section{Insert Table 3 about here}

\footnotetext{
${ }^{5}$ In unreported results, the numbers of months between the initial survey and terminal survey was positively associated with absolute hindsight bias, albeit insignificantly.
} 


\subsection{Comparison of own expectations with similar nascent activities}

Table 4 compares the expectations of nascent entrepreneurs' with how they perceive the chances of success of other similar startups after failure to launch the venture. Failed nascent entrepreneurs generally believe that the mean (median) chance of other similar startup activities becoming operational businesses is 61.3 percent (50 percent). Comparing this to the recalled expectation for their own venture's success suggests that failed entrepreneurs at the mean (median) believe other individuals have a 2.5 percent ( 0 percent) better chance of successfully creating an operating business from a similar startup activity. This difference is not statistically significant, and does not support hypothesis four. This shows that the belief that they will be more likely to succeed than their peers, which is pervasive throughout studies of individuals and entrepreneurs, is not present after failure. However, while such beliefs are tempered after nascent entrepreneurs have experienced an unfavorable outcome, it should be noted that nascent entrepreneurs still perceive that their chances of success were still similar as others even after they had failed to proceed with their venture. ${ }^{6}$

\section{Insert Table 4 about here}

\section{Discussion}

By investigating hindsight bias, this paper explores a cognitive phenomenon that we argue can directly affect the way individuals experience from engaging in the entrepreneurial process. From our results, we are able to make two principal observations. First, nascent

\footnotetext{
${ }^{6}$ Unfortunately, the PSED did not solicit perceptions of success for similar startups during the screening or first phone interview.
} 
entrepreneurs' retrospective recall of the potential for venture success is systematically biased i.e., with hindsight, they recalibrated their expectation by approximately 20 percent. Second, aside from the most formally educated, the presence of hindsight bias in the retrospective recall ability appears to be prevalent across all nascent entrepreneurs. We discuss below several ways that this research contributes to the literature and the implications of our findings.

The results presented have important implications for entrepreneurial entry. As nascent entrepreneurs systematically overestimate their chances of startup activities resulting in an operating business (Cassar, 2006b), after failure, ascertaining how accurate their estimations of success were should lead to a correction in how they evaluate the attractiveness or feasibility of future startup opportunities. However, we have established in this research that the nascent entrepreneur's ability to correct for these tendencies for future startup evaluation is hampered by their inability to correctly recall their original estimations due to hindsight bias. Further, as individuals have a tendency to over-estimate their chances of success when success depends on their own ability (Camerer \& Lovallo, 1999), by establishing the presence of hindsight bias in nascent entrepreneurs, we suggest that these individuals are at risk of overestimating their chances of success when starting future nascent activity if they do not correct for their optimistic tendencies.

Our finding that the amount of formal education influences the existence of hindsight bias makes a contribution to the extant literature by establishing a significant effect in a field experiment (Golden, 1992). Previous studies have provided little experimental evidence that hindsight bias is reduced by a professional education (Fischhoff, 1982). Contrary to expectation, the amount of previous entrepreneurial experience did not influence the existence of hindsight bias in our nascent entrepreneur sample. A potential explanation for the non-result is that those 
with previous start-up experience may be more susceptible to biases or heuristics (Busenitz \& Barney, 1997). Therefore, while the hindsight effect literature predicts experienced entrepreneurs should exhibit lower hindsight bias, the self-selection of individuals into entrepreneurship, who are more susceptible to cognitive biases, may result in the opposite effect. We consider that this finding contributes to the body of literature that examines differences between novice and serial entrepreneurs (Westhead, et al., 2005; Ucbasaran, Wright, \& Westhead, 2003). This work posits that serial entrepreneurs are able to draw upon their prior experience to better evaluate potential new venture opportunities (Shane \& Khurana, 2003). Evidence from this current research indicates that, even with previous exposure to entrepreneurship, individuals will still distort the past after their decision to quit.

While we did not examine hindsight bias present in those individuals who were successful, due to the recall question only being asked in the PSED to those who quit the process, we argue the presence of hindsight bias should not only explain the consequent behavior of nascent entrepreneurs that failed, but also those nascent entrepreneurs who succeeded. Goiten (1984) confirms that bad outcomes, like good ones, are seen as having been expected to a greater extent than they were. Similarly, entrepreneurial attribution scholars have demonstrated that those involved in the entrepreneurial process share similar experiences and attribute outcomes in a biased manner in both successful and failed outcomes (Carter et al., 1996; Gatewood, Shaver, \& Gartner, 1995; Shaver et al., 2001).

Specifically, we would assert that nascent entrepreneurs who decide to proceed with a venture may possess biases that may lead to recalling a higher or lower probability of success at a later stage. For example, as hindsight bias describes the tendency for individuals to believe after an event, that their prediction of the outcome was more accurate than it actually was, the 
existence of hindsight bias would suggest that these successful nascent entrepreneurs will recall a higher estimate of success. This would be consistent with the ex-post realization. Alternatively, attribution bias would suggest that successful nascent entrepreneurs will recall a lower ex-ante estimate of the nascent activity leading to an operating venture. A lower recalled ex-ante estimate would increase the proportion of success that is attributable to the entrepreneur's effort or ability, as would be argued by entrepreneurial attributionists, rather than due to the ease of the task. While we did not examine hindsight bias present in those individuals that were successful, due to the recall question only being asked in the PSED to those who quit the process, we argue the presence of hindsight bias should not only explain the consequent behavior of nascent entrepreneurs that failed, but also those nascent entrepreneurs who succeeded.

Our results quantify the concerns expressed by management scholars regarding the use of retrospective accounts (e.g., Golden, 1992, 1997; Huber \& Power, 1985; Schwenk, 1985). For example, Delmar and Davidsson (2000) caution that retrospective examinations of business founders involve limitations due to the potential risk of contamination because of hindsight bias (see also Bukszar \& Connolly, 1988; Fischoff \& Beyth, 1975). More broadly, this research contributes to the literature of cognitive biases that affect entrepreneurial beliefs and behavior (Baron, 2000; Cooper et al., 1988; Kahneman, et al., 1982; Simon, Houghton, \& Aquino, 2000). Hindsight bias, one of the most frequently cited cognitive biases (Christensen-Szalanski \& Beach, 1984; Guilbault et al., 2004), has received limited attention in the entrepreneurial context. We contribute by providing empirical evidence of hindsight bias in nascent entrepreneurs, describing how this bias affects or even prevents learning from failed nascent activity, and in turn, influences future nascent activity (Westhead et al., 2005). As a result, the findings have 
important implications for research investigating why individuals undertake startup activity or enter self-employment.

As field studies that examine hindsight bias are scarce, we consider this research also makes a methodological contribution. Most hindsight bias investigations are laboratory-based and use convenient samples (Christensen-Szalanski \& Willham, 1991; Guilbault et al., 2004). As the PSED identifies and surveys individuals in the process of starting new ventures and longitudinally tracks the startup process into eventual operation or inactivity, the use of the PSED to investigate hindsight bias addresses methodological limitations in previous hindsight bias research. The implications of our research also render our findings important for scholars and practitioners from within, and outside, the entrepreneurship and management domains.

Specifically, the ubiquitous and systematic nature of hindsight bias highlighted in this paper lends itself to future research that investigates what elements of the nascent process are more or less susceptible to hindsight bias. The research focus of the current project was motivated by the importance of individuals' ex-ante expectations of success on vocational choice and undertaking nascent activity (e.g., Gatewood et al., 1995). However, the recalled expectation of operational success is only one of many potential recollections that may be important for nascent entrepreneurial activity. Individual recollections are influenced by heuristics (Busenitz \& Barney, 1997) and vary by saliency, and consequently, different beliefs or activities may be recalled more accurately than others. For example, the number of competitors may be more easily and accurately recalled than the perceived strength of competition. Examining multiple recollections would provide insight into which recollections are more susceptible to hindsight, and other recall, bias. 
Empirical examination of what recollections, and their associated hindsight bias, are more influential in affecting entrepreneurial learning from nascent activity would provide greater insight into how the recalled entrepreneurial experience affects future entrepreneurial action. For example, recalling a stronger strength of competition allows the entrepreneur to attribute failure to external competitive forces over potential internal reasons, reducing the likelihood that the individual will learn about potential deficiencies in their entrepreneurial abilities. However, recalling that they expected strong competition reduces the likelihood that the individual will become aware of potential deficiencies in their ability to forecast entrepreneurial opportunities. With regard to expectations of success, researchers could consider more narrowly defined expectations of success, such as success dealing with financial institutions, and success with attracting customers. From this, the extent to which recollections of expected success effect entrepreneurs' self-beliefs after nascent activity can be established, both in regard to their ability to undertake activities successfully and their ability to estimate the likelihood of successful venturing outcomes.

Likewise, a more finite temporal understanding could be established by tracking the recalled state of relationships with key stakeholders over the duration of the nascent activity. Entrepreneurs' recall may be further contrast through surveying multiple stakeholders including other members of the founding team, family members, financiers and employees. Further, as evidence shows that hindsight bias can be reduced (Fischhoff, 1982) when individuals report how alternative outcomes would have occurred, such as successful venture launch (Slovic \& Fischhoff, 1977), there is potentially benefit in constructing processes for failed entrepreneurs that may reduce this bias. However, Buksar and Connolly (1988) caution that hindsight bias is a stubborn phenomenon and is likely to persist even when clear warnings of the effect are given 
and tasks are restructured. Hence, a longitudinal design with detailed documentation of recollections from multiple perspectives, and that continually warn of the potential influence of hindsight effects, would enable a better understanding of the role of hindsight bias and the effectiveness of prior decisions.

Building on the underlying theme of this paper that important lessons go unlearned due to the affect of hindsight bias, research using a framework such as experimental learning theory could examine if, or how, different individual learning styles are affected by hindsight bias (Kolb, 1971, 1984; Kolb, Boyatzis, \& Mainemelis, 2000). For example, nascent entrepreneurs with an accommodating learning style learn primarily from hands-on experience and enjoy carrying out plans and involving themselves in challenging experiences. In solving problems, individuals with an accommodating learning style rely more heavily on people for information than on their own technical analysis. Hindsight bias may be less prevalent for them than for, say, nascent entrepreneurs with an assimilating learning style, who are less focused on people and more interested in ideas and abstract concepts, and therefore better at understanding a wide range of information and putting into concise, logical form. Research that establishes the role of hindsight bias in individuals immersed in nascent activity according to their individual learning style would provide a finer interpretation of the influence of a hindsight effect. Framing any additional hindsight effect studies around 'learning through experience' concepts is consistent with psychology scholars who view hindsight bias as a consequence of learning by feedback (Hoch \& Loewenstein, 1989; Hoffrage, Hertwig, \& Gigerenzer, 2000) and emphasizes the importance of individual differences to the entrepreneurship process (Shane, 2000).

Research on social cognition (Shaver \& Scott, 1991) could also provide useful frameworks when linked to the affect of hindsight bias in entrepreneurial decision-making and 
risk-taking behavior (Palich \& Bagby, 1995). For example, what is the role of hindsight bias as a coping mechanism as a consequence of entrepreneurial failure (Harrison \& March, 1984)? The grief literature has established that the process of grief recovery, defined as that point when thoughts of the loss do not evoke a negative emotional response, is classifiable either as through a loss orientation or a restoration orientation (Shepherd, 2003). A loss-orientated approach to grief is a process by which the individual works through the event about which they are grieving with the end result being that the way the event is interpreted changes (Archer, 1999). For entrepreneurs who experience business failure, this can involve directing thoughts to the positive aspects of the business experience and away from the negative aspects leading up to the business closure. Interestingly, hindsight bias may assist a loss orientated approach to grief by allowing individuals to interpret previous negative aspects less negatively than achieved with perfect recall. Conversely, a restoration orientation sees the individual actively distracting themselves from the loss in order to speed up their recovery from grief. This process involves the person busying themselves so that they minimize loss-related thoughts. Consequently, those who adopt a restoration orientation to grief, thereby avoiding immediate focus on their entrepreneurial experience, may actually increase the likelihood that this experience is recalled with hindsight bias. Studying linkages between hindsight bias and entrepreneurs' grieving as a consequence of business failure would shed light on how hindsight bias functions as a coping mechanism or means of regulating self perceptions that might affect subsequent entrepreneurial behavior.

The argument and empirical analyses in this paper have focused on hindsight bias, and how this affects individuals immersed in nascent entrepreneurship. However, we recognize that hindsight bias is one of many potential cognitive influences that may affect venturing activity, and that implications will extend beyond the nascent entrepreneur's opportunity recognition or 
venture evaluation process. For example, other factors, such as those espoused in attribution theory may affect whether individuals better understand their own ability in an unbiased manner, as often assumed in economic models, as a result of undertaking action (Gervais \& Odean, 2001). Hence, we believe cognitive theories offer opportunity to provide additional insight into how learning from venturing activity can enrich economic models, which are based purely on statistically based learning.

\section{Conclusion}

This paper documents and discusses the tendency of individuals to incorrectly recall their perceived probability of success, namely the creation of an operating business, from their nascent startup activity. Consistent with hindsight bias, we observe that unsuccessful nascent entrepreneurs recall a lower predicted probability of their startup activity resulting in an operating business, than they did during the nascent activity. Research suggests that entrepreneurs who fail in their nascent or business activity, thereby incurring the costs of failure, will benefit from immersion in the process. The evidence from this study suggests it is important to recognize that what nascent entrepreneurs believe they experienced, and what they actually experienced, may not be equivalent. 


\section{References}

Archer, J. 1999. The nature of grief: The evolution and psychology of reaction to loss. Routledge: New York.

Arthur, W. B. 1993. On designing economic agents that behave like human agents. Journal of Evolutionary Economics 3(1): 1-22.

Baron, R. A. 2000. Counterfactual thinking and venture formation: The potential effects of thinking about "what might have been.” Journal of Business Venturing 15(1): 79-91.

Bird, B. 1992. The operation of intentions in time: The emergence of the new venture. Entrepreneurship Theory and Practice 17(1): 11-20.

Bukszar, E., \& Connolly, T. 1988. Hindsight bias and strategic choice: Some problems in learning from experience. Academy of Management Journal 31: 628-641.

Busenitz, L. W., \& Barney, J. B. 1997. Differences between entrepreneurs and managers in large organizations: Biases and heuristics in strategic decision-making. Journal of Business Venturing 12: 9-30.

Camerer, C., \& Lovallo, D. 1999. Overconfidence and excess entry: An experimental approach. The American Economic Review 89(1): 306-318.

Carter, N., Gartner, W., \& Reynolds, P. 1996. Exploring start-up event sequences. Journal of Business Venturing 11: 151-166.

Cassar, G. 2006a. Entrepreneurial opportunity costs and intended venture growth. Journal of Business Venturing 21: 610-632.

Cassar, G. 2006b. Information acquisition and the rationality of entrepreneurial expectations. Paper presented at the Babson College Entrepreneurship Research Conference, Bloomington.

Christensen-Szalanski, J. J. J., \& Bushyhead, J. B. 1981. Physicians' use of probabilistic information in a real clinical setting. Journal of Experimental Psychology: Human Perception and Performance 7: 928-935

Christensen-Szalanski, J. J. J., \& Beach, L. R. 1982. Experience and the base-rate fallacy. Organizational Behavior and Human Performance 29: 270-278

Christensen-Szalanski, J. J. J., \& Beach, L. R. 1984. The citation bias: Fad and fashion in the judgment and decision literature. American Psychologist 30: 75-78.

Christensen-Szalanski, J. J. J., \& Willham, C. F. 1991. The hindsight bias: A meta-analysis. Organizational Behavior and Human Decision Processes 48: 147-168. 
Cooper, A. C., Woo, C. Y., \& Dunkelberg, W. C., 1988. Entrepreneurs’ perceived chances for success. Journal of Business Venturing 3: 97-108.

Corbett, A. C. 2005. Experiential learning within the process of opportunity identification and exploitation. Entrepreneurship Theory and Practice 29(4): 473-491.

Corbett, A. C. 2007. Learning asymmetries and the discovery of entrepreneurial opportunities. Journal of Business Venturing 22: 97-118.

Dawson, N. V., Arkes, H. R., Siciliano, C., Blinkhorn, R., Lakshmanan, M., \& Petrelli, K. 1988. Hindsight bias: An impediment to accurate probability estimation in clinicopathologic conferences. Medical Decision Making: An International Journal of the Society for Medical Decision Making 8(4): 259-264.

Dearborn, D. C. \& Simon, H. A. 1958. Selective perception: A note on the departmental identifications of executives. Sociometry 21: 140-144.

Delmar, F., \& Davidsson, P. 2000. Where do they come from? Prevalence and characteristics of nascent entrepreneurs. Entrepreneurship and Regional Development 12: 1-23.

Dutta, D. K., \& Crossan, M. M. 2005. The nature of entrepreneurial opportunities: Understanding the process using the 41 organizational learning framework. Entrepreneurship Theory and Practice 29(4): 425-449.

Erdfelder, E., \& Buchner, A. 1998. Decomposing the hindsight bias: A multinomial processing tree model for separating recollection and reconstruction in hindsight. Journal of Experimental Psychology: Learning, Memory, and Cognition 24: 387-414.

Fischhoff, B. 1975. Hindsight does not equal foresight: The effect of outcome knowledge on judgment under uncertainty. Journal of Experimental Psychology: Human Perception and Performance 1: 288-299.

Fischhoff, B. 1982. Debiasing. In D. Kahneman, P. Slovic, \& A. Tversky (Eds.), Judgment Under uncertainty: Heuristics and biases. New York, NY: Cambridge University Press.

Fischhoff, B., \& Beyth, R 1975. I knew it would happen: Remembered probabilities of oncefuture things. Organizational Behavior and Human Performance 13: 1-16.

Gartner, W. 1985. A conceptual framework for describing the phenomenon of new venture creation. Academy of Management Review 10(4): 696-706.

Gartner, W. B., Shaver, K. G., Carter, N. M., \& Reynolds, P. D. 2004. (Eds.) Handbook of entrepreneurial dynamics: The process of business creation. Thousand Oaks: Sage. 
Gatewood, E. J., Shaver, K. G., \& Gartner, W. B. 1995. A longitudinal study of cognitive factors influencing start-up behaviors and success at venture creation. Journal of Business Venturing 10(5): 371-392.

Gervais, S., \& Odean, T. 2001. Learning to be overconfident. Review of Financial Studies 14(1): $1-27$.

Gimeno, J., Folta, T. B., Cooper, A. C., \& Woo, C. Y. 1997. Survival of the fittest? Entrepreneurial human capital and the persistence of underperforming firms. Administrative Science Quarterly 42: 750-783.

Goiten, B. 1984. The danger of disappearing postdecision surprise: Comment on Harrison and March “Decision Making and Postdecision Surprises.” Administrative Science Quarterly 29: 410-413.

Golden, B. R. 1992. The past is the past: Or is it? The use of retrospective accounts as indicators of past strategy. Academy of Management Journal 35(4): 848-860.

Golden, B. R. 1997. Further remarks on retrospective accounts in organizational and strategic management research. Academy of Management Journal 40(5): 1243-1252.

Guilbault, R. L., Bryant, F. B., Howard Brockway, J. \& Posavac, E. J. 2004. A meta-analysis of research on hindsight bias. Basic and Applied Social Psychology 26(2\&3): 103-117.

Harrison, R. T, \& Leitch C. M. 2005. Entrepreneurial learning: Researching the interface between learning and the entrepreneurial context. Entrepreneurship Theory and Practice 29(4): 351-371.

Harrison, R. J., \& March, J. G. 1984. Decision making and postdecision surprises. Administration Science Quarterly 29: 26-42.

Hawkins, S. A., \& Hastie, R. 1990. Hindsight: Biased judgments of past events after the outcomes are known. Psychological Bulletin 107: 311-327.

Heider, F. 1958. The psychology of interpersonal relations. New York: Wiley.

Hertwig, R., Fanselow, C., \& Hoffrage, U. 2003. Hindsight bias: How knowledge and heuristics affect our reconstruction of the past. Memory 11(4/5): 357-378.

Hoang, H. J., \& Gimeno, J. 2005. Becoming an entrepreneur: A theory of entrepreneurial identity. Insead Working Papers.

Hoch, S. J., \& Loewenstein, G. F. 1989. Outcome feedback: Hindsight and information. Journal of Experimental Psychology: Learning, Memory, and Cognition 15, 605-619. 
Hoffrage U., Hertwig R., \& Gigerenzer G. 2000. Hindsight bias: A by-product of knowledge updating? Journal of Experimental Psychology: Learning, Memory, and Cognition, 26 (3), $566-581$.

Honig, B., Davidsson, P., \& Karlsson, T. 2005. Learning strategies of nascent entrepreneurs. Journal of Competence-based Management 1(3): 67-88.

Huber, G. P., \& Power, D. J. 1985. Retrospective reports of strategic-level managers: Guidelines for increasing their accuracy. Strategic Management Journal 6(2): 171-180.

Jovanovic, B. 1979. Job matching and the theory of turnover. Journal of Political Economy 87(5): 972-990.

Kolb, D. A. 1971. Individual learning styles and the learning process. Working Paper \#535-71, Sloan School of Management, Massachusetts Institute of Technology.

Kolb, D. A. 1984. Experiential learning: Experience as the source of learning and development. New Jersey: Prentice-Hall.

Kolb, D. A., Boyatzis, R. E., \& Mainemelis, C. 2000. Experiential learning theory: Previous research and new directions. In R. J. Sternberg and L. F. Zhang (Eds.), Perspectives on cognitive, learning, and thinking styles. NJ: Lawrence Erlbaum, 2000.

Kahneman, D., Slovic, P., \& Tversky, A. 1982. Judgment under uncertainty: Heuristics and biases. New York, NY: Cambridge University Press.

Kelley, H. H. 1972. Attribution in social interaction. In E. E. Jones, D. E. Knouse, H. H. Kelley, R. E. Nisbett, S. Valins, \& B. Weiner (Eds.), Attribution: Perceiving the causes of behavior (pp. 1-26). Morristown, NJ: General Learning Press.

Lamont, L. 1972. What entrepreneurs learn from experience. Journal of Small Business Management 10(3): 36-41.

Larwood, L., \& Whittaker, W. 1977. Managerial myopia: Self-serving biases in organizational planning. Journal of Applied Psychology 62: 94-198.

Lumpkin, G. T., \& Lichtenstein B. B. 2005. The role of organizational learning in the opportunity-recognition process. Entrepreneurship Theory and Practice 29(4):451-472.

Maidique, M. A., \& Zirger, B. J. 1984. A study of success and failure in product innovation: The case of the U.S. electronics industry. IEEE Transactions on Engineering Management 31: 192-203.

McGrath, R. G. 1999. Falling forward: Real options reasoning and entrepreneurial failure. Academy of Management Review 24(1): 13-30. 
McMullen, J. S. \& Shepherd, D. A. 2006. Entrepreneurial action and the role of uncertainty in the theory of the entrepreneur. Academy of Management Review 31(1): 132-152.

Minniti, M., \& Bygrave, W. 2001. A dynamic model of entrepreneurial learning. Entrepreneurship Theory and Practice 25(3): 5-16.

Nonaka, I., \& Takeuchi, H. 1995. The knowledge creating company. New York: Oxford.

Olson, J. M., Roese, N. J., \& Zanna, M. P. 1996. Expectancies. In E. T. Higgins \& A. W. Kruglanski (Eds.), Social Psychology: Handbook of Basic Principles. New York: Guildford.

Parker, S. C. 2006. Learning about the unknown: How fast do entrepreneurs adjust their beliefs? Journal of Business Venturing 21(1): 1-26.

Palich, L. E. \& Bagby, R. 1995. Using cognitive theory to explain entrepreneurial risk-taking: Challenging conventional wisdom Journal of Business Venturing 10(6): 425-438

Politis, D. 2005. The process of entrepreneurial learning: A conceptual framework. Entrepreneurship Theory and Practice 29(4): 399-424.

Reynolds, P. D. 1997. Who starts new firms? Preliminary explorations of firms-in-gestation. Small Business Economics 9: 449-462.

Riechmann, T. 1999. Learning and behavioral stability: An economic interpretation of genetic algorithms. Journal of Evolutionary Economics 9(2): 225-242.

Roese, N. J., \& Olson, J. M. 1996. Counterfactuals, causal attributions, and the hindsight bias: A conceptual integration. Journal of Experimental Social Psychology 32: 197-227.

Ronstadt, R. 1988. The corridor principal. Journal of Business Venturing 3(1): 31-40.

Sarasvathy, S. D. 2001. Causation and effectuation: Toward a theoretical shift from economic inevitability to entrepreneurial contingency. Academy of Management Review 26(2): 243263.

Schkade, D. A., \& Kilburne, L. M. 1991. Expectation-outcome consistency and hindsight bias. Organization Behavior and Human Decision Processes 49: 105-123.

Schwenk, C. 1985. The use of participant recollection in modeling of organizational decision processes. Academy of Management Review 10: 496-503.

Sexton, D. L., Upton, N. B., Wacholtz, L. E., \& McDougall, P. P. 1997. Learning needs of growth-oriented entrepreneurs. Journal of Business Venturing 12(1): 1-8. 
Shane, S. 2000. Prior knowledge and the discovery of entrepreneurial opportunities. Organizational Science 11(4): 448-469.

Shane, S., \& Venkataraman, S. 2000. The promise of entrepreneurship as a field of research. Journal of Business Venturing 25: 217-226.

Shane, S., \& Khurana, R. 2003. Bringing individuals back in: The effects of career experience on new firm founding. Industrial and Corporate Change 12(2): 519-544.

Shaver, K. G. 1985. Attribution of blame: Causality, responsibility, and blameworthiness. New York: Springer-Verlag.

Shaver, K. G., Gartner, W. B., Crosby, E., Bakalarova, K., \& Gatewood, E. J. 2001. Attributions about entrepreneurship: A framework and process for analyzing reasons for starting a business. Entrepreneurship Theory and Practice Winter: 5-32.

Shaver, K. G., \& Scott, L. R. 1991. Person, process, choice: the psychology of new venture creation. Entrepreneurship Theory and Practice 16(2): 23-45.

Shepherd, D. A. 2003. Learning from business failure: Propositions of grief recovery for the selfemployed. Academy of Management Review 28(2): 318-328.

Simon, M., Houghton, S. M., \& Aquino, K. 2000. Cognitive biases, risk perception, and venture formation: How individuals decide to start companies. Journal of Business Venturing 15: $113-134$.

Sitkin, S. B. 1992. Learning through failure: The strategy of small losses. In B. M. Staw \& L. L. Cummings (Eds.). Research in organizational behavior 14: 231-266. Greenwich, CT: JAI Press.

Slovic, P., \& Fischhoff, B. 1977. On the psychology of experimental surprises. Journal of Experimental Psychology: Human Perception and Performance 3: 544-551.

Starr, J. A., \& Bygrave, W. D. 1992. The second time around: The outcomes assets, and liabilities of prior start-up experience. In S. Birley \& I. C. MacMillan (Eds.), International perspectives on entrepreneurship research 1991: Proceedings of the first annual global conference on entrepreneurship research: 340-363. Amsterdam, The Netherlands.

Swann, W. B. 1997. The trouble with change: Self-verification and allegiance to self. Psychological Science 8(3): 177-180.

Swann, W. B., \& Hill, C. A. 1982. When our identities are mistaken: Re-affirming selfconceptions through social interaction. Journal of Personality and Social Psychology 43: 59-66. 
Taylor, R. N. 1975. Age and experience as determinants of information processing and decisionmaking performance. Academy of Management Journal 18(1): 74-81.

Taylor, S. E., \& Brown, J. D. 1988. Illusion and well-being: A social psychological perspective on mental health. Psychological Bulletin 103: 193-210.

Ucbasaran, D., Wright, P., \& Westhead, M. 2003. A longitudinal study of habitual entrepreneurs: Starters and acquirers. Entrepreneurship and Regional Development 15(3): 207-228.

Van der Steen, E. 2004. Rational overoptimism (and other biases). American Economic Review 94(4): 1141-1151.

Wasserman, D., Lempert, R. O., \& Hastie, R. 1991. Hindsight and causality. Personality and Social Psychology Bulletin 17: 30-35.

Weiner, B. 1985. An attributional theory of achievement motivation and emotion. Psychological Review 92: 548-573.

Weiner, B., \& Kulka, A. 1970. An attributional analysis of achievement motivation. Journal of Personality and Social Psychology 15: 1-20.

Weinstein, N. D. 1982. Unrealistic optimism about susceptibility to health problems. Journal of Behavioral Medicine 441-446.

Westhead, P., Ucbasaran, D., \& Wright, M. 2005. Decisions, actions, and performance: Do novice, serial, and portfolio entrepreneurs differ? Journal of Small Business Management 43(4): 393-417. 
Table 1

Expectations and hindsight bias

\begin{tabular}{|c|c|c|c|c|c|c|c|}
\hline Variables & Mean & s.d. & $25 \%$ & Median & $75 \%$ & $\begin{array}{c}t \text {-test } \\
\text { statistic }\end{array}$ & $\begin{array}{l}\text { Signed } \\
\text { rank }\end{array}$ \\
\hline Initial expectation & 77.27 & 25.32 & 60.00 & 80.00 & 100.00 & & \\
\hline Recalled expectation & 58.76 & 26.14 & 50.00 & 50.00 & 80.00 & & \\
\hline Hindsight bias & 18.51 & 33.56 & 0.00 & 20.00 & 45.00 & $7.76 * * *$ & $4388 * * *$ \\
\hline $\begin{array}{l}\text { Absolute hindsight } \\
\text { bias }\end{array}$ & 30.42 & 23.25 & 10.00 & 25.00 & 50.00 & & \\
\hline $\begin{array}{l}n=198 \text { (two-tailed). } \\
\dagger p<.10 \\
* \mathrm{p}<.05 \\
* * \mathrm{p}<.01 \\
* * * \mathrm{p}<.001\end{array}$ & & & & & & & \\
\hline
\end{tabular}


Table 2

Correlations among variables ${ }^{\mathrm{a}}$

\begin{tabular}{lcrrrrrr}
\hline \multicolumn{1}{c}{ Variable } & Mean & \multicolumn{1}{c}{1} & 2 & 3 & 4 & 5 & 6 \\
\hline 1. Hindsight bias & 18.51 & & & & & & \\
2. Months elapsed & 33.10 & -.05 & & & & & \\
3. Age & 38.44 & $-.14 *$ & .02 & & & & \\
4. Startup experience & 0.45 & -.00 & -.02 & .07 & & & \\
5. Education (no college) & 0.25 & -.02 & $-.14 *$ & -.08 & $.13 \dagger$ & & \\
6. Education (some college) & 0.60 & $.17 *$ & $.15 *$ & $-.14 \dagger$ & -.08 & $-.71^{* * *}$ & \\
7. Education (post college) & 0.15 & $-.21^{* *}$ & -.03 & $.29 * * *$ & -.06 & $-.24 * * *$ & $-.51^{* * *}$ \\
\hline
\end{tabular}

${ }^{\text {a }}$ Correlations (two-tailed) are based on $n=198$, except for age, where $n=194$.

$\dagger \mathrm{p}<.10$

$* \mathrm{p}<.05$

$* * \mathrm{p}<.01$

$* * * \mathrm{p}<.001$ 
Table 3

Results of regression analysis for hindsight bias ${ }^{\mathrm{a}}$

\begin{tabular}{|c|c|c|c|}
\hline Independent Variables & Coefficient & Standard Error & $\mid t$-test statistic $\mid$ \\
\hline Constant & $25.73 *$ & 10.21 & 2.52 \\
\hline Months elapsed & -0.07 & 0.13 & 0.56 \\
\hline Age & -0.21 & 0.22 & 0.98 \\
\hline Startup experience & 1.82 & 4.82 & 0.38 \\
\hline \multicolumn{4}{|l|}{ Education } \\
\hline Some college & 7.54 & 5.71 & 1.32 \\
\hline Post college & $-16.07^{*}$ & 8.01 & 2.01 \\
\hline Adj. $R^{2}$ & .050 & & \\
\hline & .075 & & \\
\hline F-stat & $3.04^{*}$ & & \\
\hline $\begin{array}{l}n=194 \text { (two-tailed). } \\
\dagger \mathrm{p}<.10 \\
* \mathrm{p}<.05 \\
* * \mathrm{p}<.01 \\
* * * \mathrm{p}<.001\end{array}$ & & & \\
\hline
\end{tabular}


Table 4

Expectation after failed nascent activity

\begin{tabular}{|c|c|c|c|c|c|c|c|}
\hline Variables & Mean & s.d. & $25 \%$ & Median & $75 \%$ & $\begin{array}{c}\text { t-test } \\
\text { statistic }\end{array}$ & $\begin{array}{l}\text { Signed } \\
\text { rank }\end{array}$ \\
\hline $\begin{array}{l}\text { Similar business } \\
\text { expectation }\end{array}$ & 61.25 & 26.27 & 50.00 & 50.00 & 80.00 & & \\
\hline Recalled expectation & 58.76 & 26.14 & 50.00 & 50.00 & 80.00 & & \\
\hline Difference & -2.49 & 31.22 & -20.00 & 0.00 & 10.00 & 1.12 & 618 \\
\hline
\end{tabular}

$n=198$ (two-tailed).

$\dagger \mathrm{p}<.10$

$* \mathrm{p}<.05$

$* * \mathrm{p}<.01$

$* * * \mathrm{p}<.001$ 